\title{
DESCRIPTION OF A FELINE INJECTION-SITE FIBROSARCOMA WITH METASTASIS IN THE CEREBELLUM
}

\author{
CORA Roxana, GAL Adrian Florin*, TAULESCU Marian, TĂBĂRAN Flaviu, \\ VIDRIGHINESCU Raluca, CĂTOI Cornel
}

Department of Pathology, Faculty of Veterinary Medicine, University of Agricultural Sciences and Veterinary Medicine Cluj-Napoca, Calea Mănăştur 3-5, Cluj-Napoca, 400372, Romania

(Received 26 April, Accepted 14 July 2017)

Feline injection-site sarcomas were initially described by Hendrick and Goldschmidt (1991). The link between vaccination site and sarcoma occurrence suggested the term of vaccine-associated sarcomas. Our paper describes an unusual feline injection-site fibrosarcoma with cerebellar metastasis. A 7-year-old female domestic short-hair cat was submitted to the Pathology Department (Faculty of Veterinary Medicine ClujNapoca, Romania) for necropsy. A subcutaneous tumor (relapse) in the interscapular region and multiple metastatic masses in the lungs, kidneys, subcutaneous tissue (scapular and thigh regions) and cerebellum were observed. Cytological, histological and immunohistochemical (for vimentin, desmin, multi-cytokeratin, $\alpha$-smooth muscle actin, S100 and CD45) analyses from all tumors were performed. Cytological examination identified highly pleomorphic spindle-shaped cells admixed with neoplastic multinucleated giant cells. Histologically, all neoplastic masses were composed of numerous spindle cells arranged into interlacing bundles. Extensive intratumoral areas of necrosis along with a neutrophilic infiltrate were also detected. A fibrillary material was present among neoplastic cells (green stained by Masson's trichrome method), suggesting a collagenous structure. In all tumors assessed, immunohistochemistry showed an intense reaction only for vimentin in numerous neoplastic cells. Based on the history, gross, cytological, histological and immunohistochemical data, the final diagnosis was recurrent feline injection-site fibrosarcoma, with multiple metastases (including in the cerebellum). Overall, an uncommon case of feline injection-site fibrosarcoma has been reported. This is the first consistent record of an injection site sarcoma in a cat with cerebellar metastasis.

Key words: cerebellum, feline injection-site fibrosarcoma, metastasis

\section{INTRODUCTION}

Feline injection-site sarcomas (FISS) were initially described by Hendrick and Goldschmidt (1991) [1]. The link between vaccination and the increased incidence of sarcoma occurrence, suggested the term of vaccine-associated sarcomas (or injectionsite sarcomas). However, recent studies showed that other foreign materials injected

\footnotetext{
*Corresponding author: e-mail: adrian.gal@usamvcluj.ro
} 
in the muscular or subcutaneous tissues can trigger a local chronic inflammation and neoplastic transformation [2]. In most circumstances, FISS were associated with inactivated anti-rabies and anti-feline leukemia virus vaccines. Both vaccine types contain aluminum as adjuvant [3,4] that is capable to trigger a chronic inflammation (i.e., granulomatous reaction) at the site of vaccination [4,5]. However, some reports demonstrated no significant difference in the incidence of sarcomas with regard to vaccines with or without adjuvant materials $[4,6]$. The prevalence of FISS in vaccinated subjects range from $1 / 1.000$ to $1 / 10.000[7,8]$. FISS are regularly occurring in 10 years old subjects (average age), with some peaks in 6-7 and 10-11 years old cats, respectively. A slightly higher incidence was noticed in females compared to males; no breed predisposition was observed $[4,6,9,10]$.

The current report describes an unusual feline site-injection fibrosarcoma (FSIF) with cerebellar metastasis. According to our knowledge, this is the first report of a FISS in the central nervous system.

\section{CASE PRESENTATION}

\section{Case History}

A 7-year-old neutered female domestic short-hair cat was sent to the Pathology Department, Faculty of Veterinary Medicine Cluj-Napoca (Romania), for a complete necropsy survey. The cat was neutered at the age of two years. In 2015, the cat displayed a tumor in the interscapular region (i.e., vaccination site) that was surgically removed. The mass was diagnosed histologically as FISS. Six months later the cat presented respiratory distress and neurological signs (e.g., ataxia, abnormal positions of the head, ingestion failure etc.). Due to welfare reasons, the cat was humanely euthanized.

\section{Necropsy}

Grossly, the cat presented anemia and cachexia; in the subcutaneous tissue of the interscapular region, a firm, white-gray, nodular mass was detected (Figure 1A). The tumor had $1.1 \mathrm{~cm}$ in size with a central necrotic area in cross section. Similar nodular lesions affecting the kidneys (Figure 1B), the left lobe of the cerebellum (Figure 1C) and the lungs (Figure 1D) were present. The pulmonary nodules had about $0.3-1 \mathrm{~cm}$; renal masses ranged from 0.2 to $0.7 \mathrm{~cm}$ in diameter, while the cerebellar tumor had $1.2 \mathrm{~cm} / 1 \mathrm{~cm}$. Additionally, two more metastases were identified in the subcutaneous tissue (a mass was located in the left thigh region $-1.8 / 1.6 \mathrm{~cm}$ in diameter, and another one in the right scapular region $-0.9 / 0.7 \mathrm{~cm}$ in size).

\section{Cytology and histopathology}

Cytological smears were performed from all nodular lesions using touch imprint method and were stained by Dia Quick Panoptic technique (DQP, Reagens Kft, Budapest, Hungary). Cytological examination identified a large number of poorly differentiated spindle neoplastic cells, disposed individually or in groups. Numerous neoplastic multinucleated giant cells were also observed (Figure 2A); a high number of 
tumor cells were in the mitotic phase (29 mitoses/10 HPF). The cytological features described above are compatible with the diagnosis of a malignant mesenchymal tumor (sarcoma).

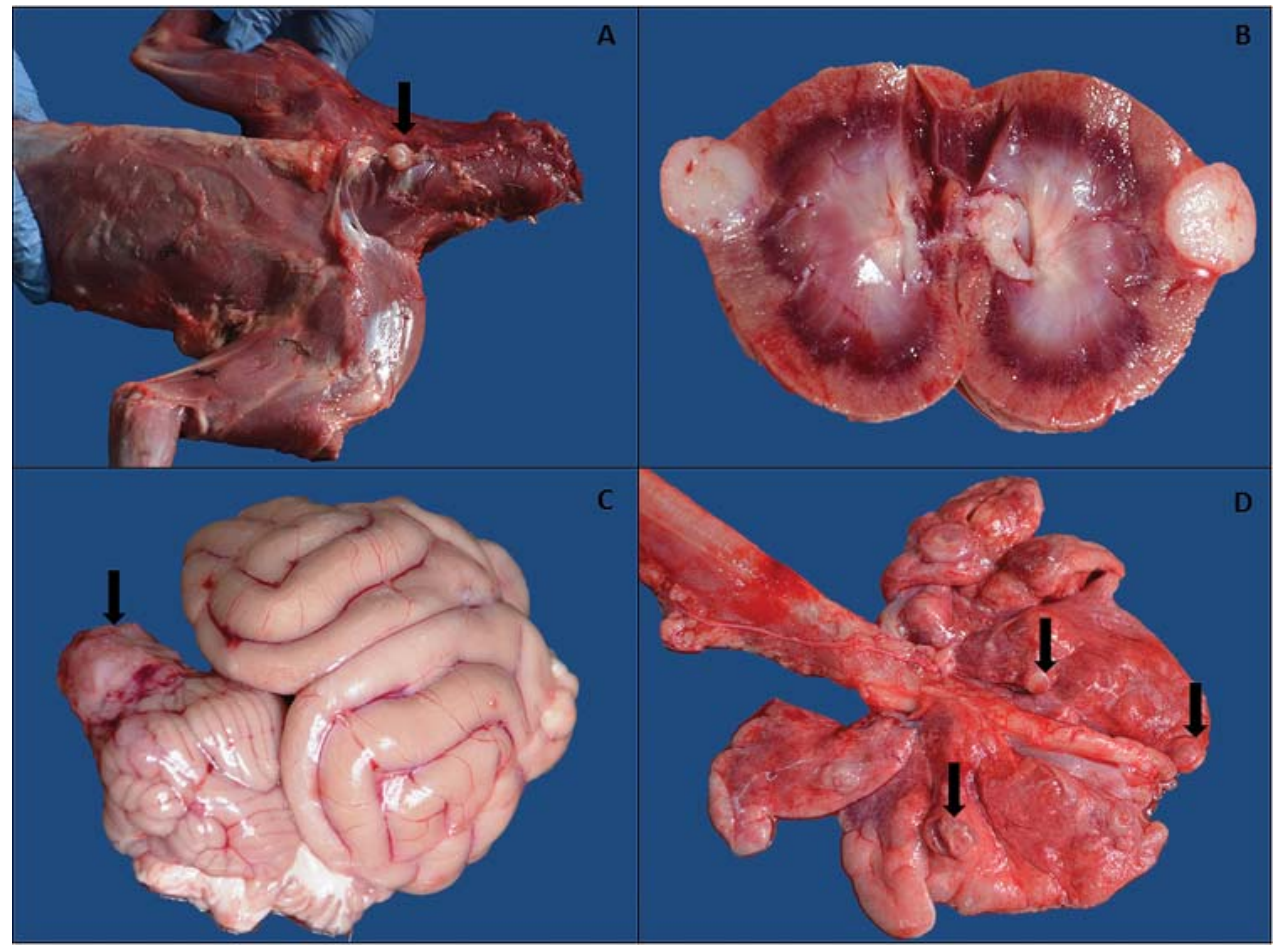

Figure 1. FSIF: (A) interscapular tumor mass (black arrow); (B) tumor mass in the kidney; (C) neoplastic mass in the cerebellum (left lobe) (black arrow); (D) multiple neoplastic nodules in the lungs (black arrows).

For histology, the tumor samples were fixed in 10\% phosphate buffered formalin $(\mathrm{pH}$ 7.0) for 24 hours and routinely processed by paraffin technique. The achieved slides were stained by hematoxylin-eosin (HE) and Masson's trichrome (M'T) methods. The recurrent interscapular mass was well demarcated, unencapsulated, highly cellular and mainly composed of spindle cells arranged into variably-sized interlacing bundles. Neoplastic cells showed poorly defined borders, small amount of pale eosinophilic and slightly fibrillar cytoplasm, oval to elongate and vesicular nuclei, and 1-3 prominent variably-sized magenta nucleoli (Figure 2B). Multifocally, some multinucleated neoplastic cells were observed. A high number of mitotic figures were identified (105 mitoses/10 HPF), some of them showing atypical features. An eosinophilic fibrillary material was present among neoplastic cells of the tumor. The fibrillary material was stained in green by Masson's trichrome method, suggesting a collagenous structure (Figure 2D). Peripherally, the tumor was multifocally infiltrated by aggregates of lymphocytes (Figure 2B). However, in the central part of the tumor, extensive areas of necrosis along with neutrophilic infiltrate and hemorrhages were observed. All the other masses identified in the carcass (including the one in the cerebellum) presented 
the same histological features described above (Figure 2C). The cerebellar mass was unencapsulated, infiltrative and poorly delimited from the adjacent nervous tissue.

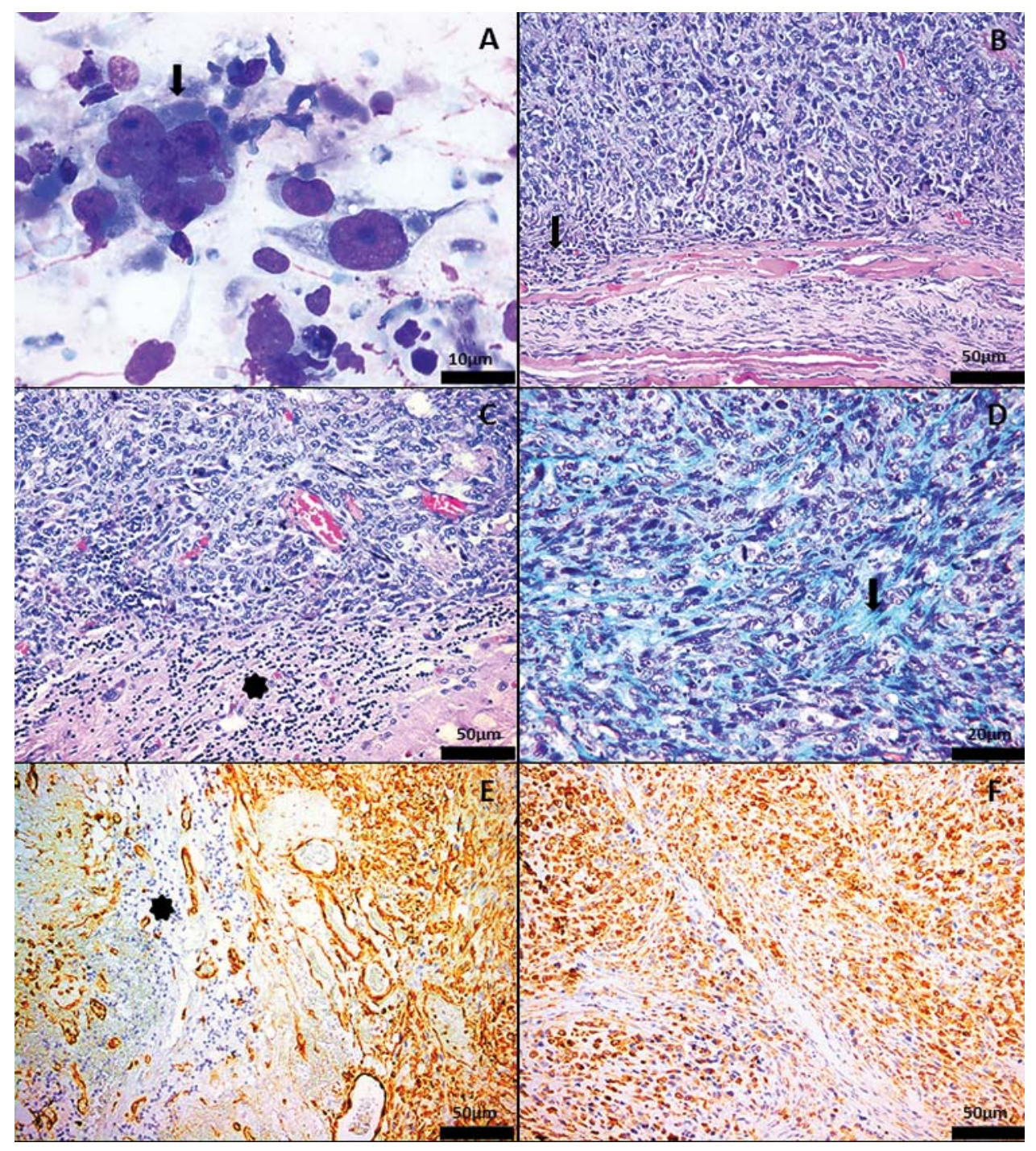

Figure 2. FSIF: (A) cytological smear from the cerebellar mass - numerous neoplastic spindle and multinucleated giant cells (black arrow), DQP stain; (B) primary subcutaneous interscapular tumor - bundles of pleomorphic tumor cells and lymphocytic infiltration at the periphery of the tumor (black arrow), HE stain; (C) cerebellar metastasis - borderline of the tumor in cerebellum substance (star showing the grey matter of the cerebellum), HE stain; (D) primary interscapular tumor: the presence of collagenous structures among neoplastic cells (arrow), MT stain; (E) IHC, cerebellar metastasis - positive reaction for vimentin in the cytoplasm of tumoral cells (star showing the cerebellar grey matter), IHC reaction and Mayer's haematoxylin counterstain; (F) IHC, primary interscapular tumor - diffusely and intensely positive reaction for vimentin in the cytoplasm of neoplastic cells, IHC reaction and Mayer's haematoxylin counterstain. 


\section{Immunohistochemistry}

Immunohistochemistry was used to establish the final diagnosis and origin of all tumors identified throughout the body. Accordingly, the histological sections achieved by the paraffin technique were utilized; the panel of antibodies applied on the slides were: vimentin (mouse anti-human monoclonal vimentin antibody, clone SRL33, Leica Biosystems Newcastle Ltd, United Kingdom), desmin (mouse anti-human monoclonal desmin antibody, clone DE-R-11, Leica Biosystems Newcastle Ltd, United Kingdom), multi-cytokeratin (mouse anti-human multi-cytokeratin antibody, clone AE1/AE3, Leica Biosystems Newcastle Ltd, United Kingdom), $\alpha$-smooth muscle actin (rabbit polyclonal alpha-smooth muscle actin antibody, product code: ab5694, Abcam, United Kingdom), S100 (rabbit polyclonal S-100 antibody, Leica Biosystems Newcastle Ltd, United Kingdom) and CD45 (mouse anti-human monoclonal antibody, clone X16/99, Leica Biosystems Newcastle Ltd, United Kingdom). All samples were processed using the automatic Leica Bondmax ${ }^{\mathrm{TM}}$ Immunohistochemistry system (Leica Biosystems Melbourne, Bond Max model, M2 12154 series). Eventually, the obtained samples were counterstained by Mayer's hematoxylin. For all biomarkers applied, were considered positive the tumor cells that had the cytoplasm (vimentin, desmin, multicytokeratin, actin, S-100) or plasma membrane (CD45) marked in various levels of brown. For higher accuracy, the negative and positive controls were used. All samples were assessed using the Olympus BX51 microscope that was linked to an Olympus SP-350 photo-camera; the image analysis was performed with the aid of Olympus Cell B software (Olympus Corporation, Japan).

In all tumors assessed, immunohistochemistry showed an intense reaction only for vimentin in all neoplastic cells (including multinucleated giant cells; Figure $2 \mathrm{E}$ and $\mathrm{F}$ ). Concerning the other biomarkers, the IHC-reaction was negative in all masses (Table 1).

Table 1. Immunohistochemical results of the analyzed tumoral masses

\begin{tabular}{lcccccc}
\hline & Vimentin & Desmin & S-100 & $\begin{array}{c}\text { Multi- } \\
\text { cytokeratin }\end{array}$ & $\begin{array}{c}\alpha \text {-smooth } \\
\text { muscle actin }\end{array}$ & CD45 \\
\hline Interscapular mass & + & - & - & - & - & - \\
Cerebellum mass & + & - & - & - & - & - \\
Lung tumors & + & - & - & - & - & - \\
Renal tumors & + & - & - & - & - & - \\
Subcutaneous tumors & + & - & - & - & - & - \\
\hline
\end{tabular}

Based on the history, gross, cytological, histological and immunohistochemical data, the final diagnosis was recurrent FISF (feline injection-site fibrosarcoma), with multiple metastases (including in the cerebellum). 


\section{DISCUSSIONS}

FISS were regularly observed in body regions typically exposed to injection (e.g., interscapular, dorsolateral thoracic region, hind limbs and lumbar region), and occasionally in the ventral thoracic and abdominal regions [4]. FISS are aggressive and locally infiltrative tumors, facts that make difficult a complete surgical excision [4,11]. An increase in survival rate is closely related to early surgical intervention and radical excision. Thus, a survival rate of up to 576 days after surgery was reported $[4,12]$. However, even after a wide surgical excision, the relapse rate of FISS is high (45\%) $[2,13]$.

The metastatic rate of FISS varies from $10 \%$ in more recent studies, to $25 \%$ in older reports, with a much higher incidence compared to sarcomas that are not associated with vaccinations $[8,12,14-16]$. Generally, FISS metastasize to the lungs, but other locations were also reported, such as regional lymph nodes, mediastinum, liver and omentum [8,11,17,18]. Fulton et al. (1991) [19] and Cohen et al. (2003) [8] reported some unusual metastases of FISS in the eye.

Histologically, FISS may contain seldom large macrophages that display in the cytoplasm a blue to greyish material, most likely due to ingestion of adjuvant substances [20,21]. Such macrophages were observed in less than 50\% of FISS [22,23,24]. No such macrophages were observed in our study. As we observed in our subject, a follicular infiltrate composed of lymphocytes and plasma cells can be identified in the peripheral zone of FISSs [21,25]. The role of these lymphocytes in tumorigenesis and/or host response is unknown [26]. Another feature identified in the tumoral masses of the presented cat were the neoplastic multinucleated giant cells, which are common in FISS. Usually, they reveal a less differentiated tumor phenotype [26,27].

In most situations, FISS are resembling fibrosarcomas that represent up to $80-90 \%$ of all cases. However, other sarcoma types were reported, such as: osteosarcoma, condrosarcoma, myxosarcoma, rhabdomyosarcoma, malignant fibrous histiocytoma, myofibroblastic sarcoma and undifferentiated sarcoma [3,8,15,22,24,26-30].

All FISF express only vimentin [4], an aspect observed in our case too. However, in some FISF, the reactive multinucleated giant cells can express leukocyte markers CD45 and CD18, while the giant cells derived from fibroblasts express only vimentin. Myofibroblastic fibrosarcomas express $\alpha$-smooth muscle actin, and rarely they can be positive for desmin. Histiocytic sarcomas are positive for CD45 and CD18, whereas leiomyomas express the both $\alpha$-smooth muscle actin and desmin. According to that, the differentiation of myofibroblastic fibrosarcomas from leiomyomas cannot be made using immunohistochemistry [4].

Overall, an uncommon case of FISF has been reported. This is the first consistent record of an injection site sarcoma in cat with cerebellar metastasis. Herein we present gross, cytologic, histopathologic and immunohistochemical features of a FISF with brain invasion. 


\section{Authors' contributions}

CR and GAF carried out necropsy, cytological, histological and immunohistochemistry assessment and drafted the manuscript. TM and TF were involved in the acquisition, analysis and interpretation of data. VR participated in the design of the study. CC approved the ultimate form of the manuscript. All authors read and approved the final manuscript.

\section{Declaration of conflicting interests}

The author(s) declared no potential conflicts of interest with respect to the research, authorship, and/or publication of this article.

\section{REFERENCES}

1. Hendrick MJ, Goldschmidt MH: Do injection site reactions induce fibrosarcomas in cats? [abstract]. J Am Vet Med Assoc 1991, 199(8):968.

2. Martano M, Morello E, Buracco P: Feline injection-site sarcoma: past, present and future perspectives. Vet J 2011, 188(2):136-141.

3. Macy DW, Hendrick MJ: The potential role of inflammation in the development of postvaccinal sarcomas in cats. Vet Clin North Am Small Anim Pract 1996, 26(1):103-109.

4. Gross T, Ihrke PJ, Walder EJ, Affolter VK: Mesenchymal neoplasms and other tumors. In: Skin diseases of the Dog and Cat: Clinical and Histopathologic Diagnosis. Oxford, United Kindom: Blackwell Science Ltd; 2005, 722-801.

5. Hendrick MJ, Dunagan CA: Focal necrotizing granulomatous panniculitis associated with subcutaneous injection of rabies vaccine in cats and dogs: 10 cases (1988-1989). J Am Vet Med Assoc 1991, 198(2):304-305.

6. Kass PH, Spangler WL, Hendrick MJ, McGill LD, Esplin DG, Lester S, Slater M, Meyer EK, Boucher F, Peters EM, Gobar GG: Multicenter case-control study of risk factors associated with development of vaccine-associated sarcomas in cats. J Am Vet Med Assoc 2003, 223(9):1283-1292.

7. Couto CG, Macy DW: Review of treatment options for vaccine-associated feline sarcoma. J Am Vet Med Assoc 1998, 213(10):1426-1427.

8. Cohen M, Sartin EA, Whitley EM, Whitley RD, Smith AN, Brawner WR, Henderson R, Behrend EN: Ocular metastasis of a vaccine-associated fibrosarcoma in a cat. Vet Comp Oncol 2003, 1(4):232-240.

9. Kass PH, Barnes Jr WG, Spangler WL, Chomel BB, Culbertson MR: Epidemiologic evidence for a causal relation between vaccination and fibrosarcoma tumorigenesis in cats. J Am Vet Med Assoc 1993, 203(3):396-405.

10. Tennant B: Feline injection-site fibrosarcoma: results of the BSAVA survey. J Small Anim Pract 2000, 41(4):181-182.

11. Briscoe CM, Lipscomb TP, McKinney L: Pulmonary metastasis of a feline vaccination-site fibrosarcoma. J Vet Diagn Invest 1998, 10(1):79-82. 
12. Hershey AE, Sorenmo KU, Hendrick MJ, Shofer FS, Vail DM: Prognosis for presumed feline vaccine-associated sarcoma after excision: 61 cases (1986-1996). J Am Vet Med Assoc 2000, 216(1):58-61.

13. Cronin K, Page RL, Spodnick G, Dodge R, Hardie EN, Price GS, Ruslander D, Thrall DE: Radiation therapy and surgery for fibrosarcoma in 33 cats. Vet Radiol Ultrasound 1998, 39(1):51-56.

14. Hendrick MJ, Shofer FS, Goldschmidt MH, Haviland JC, Schelling SH, Engler SJ, Gliatto JM: Comparison of fibrosarcomas that developed at vaccination sites and at nonvaccination sites in cats: 239 cases (1991-1992). J Am Vet Med Assoc 1994, 205(10):1425-1429.

15. Lester S, Clemett T, Burt A: (1996) Vaccine site-associated sarcomas in cats: clinical experience and a laboratory review (1982-1993). J Am Anim Hosp Assoc 1996, 32(2):9195.

16. Cohen M, Wright JC, Brawner Jr WR, Smith AN, Henderson R, Behrend EN: Use of surgery and electron beam irradiation, with or without chemotherapy, for treatment of vaccine-associated sarcomas in cats: 78 cases (1996-2000). J Am Vet Med Assoc 2001, 219(11):1582-1589.

17. Rudmann DG, Alstine WV, Doddy F, Sandusky GE, Barkdull T, Janovitz EB: Pulmonary and mediastinal metastases of a vaccination-site sarcoma in a cat. Vet Pathol 1996, 33(4):466-469.

18. Sandler I., Teeger M., Best S: Metastatic vaccine associated fibrosarcoma in a 10-year-old cat [abstract]. Can Vet J 1997, 38(6):374.

19. Fulton LM, Bromberg NM, Goldschmidt MH: Soft tissue fibrosarcoma with intraocular metastasis in a cat. Prog Vet Comp Ophthalmol 1991, 1:129-132.

20. Morrison WB, Starr RM: Vaccine-associated feline sarcomas. J Am Vet Med Assoc 2001, 218(5):697-702.

21. Gumber S, Wakamatsu N: Vaccine-associated fibrosarcoma with keloidal differentiation in a cat. J Vet Diagn Invest 2011, 23(5):1061-1064.

22. Giudice C, Stefanello D, Sala M, Cantatore M, Russo F, Romussi S, Travetti O, Di Giancamillo M, Grieco V: Feline injection-site sarcoma: recurrence, tumour grading and surgical margin status evaluated using the three- dimensional histological technique. Vet J 2010, 186(1):84-88.

23. Dean RS, Pfeiffer DU, Adams VJ: The incidence of feline injection site sarcomas in the United Kingdom. BMC Vet Res 2013, 9(1):17.

24. Kliczkowska K, Jankowska U, Jagielski D, Czopowicz M, Sapierzyński R: Epidemiological and morphological analysis of feline injection site sarcomas. Pol J Vet Sci. 2015, 18(2):313322.

25. Dubielzig RR: Ocular sarcoma following trauma in three cats. J Am Vet Med Assoc 1984, 184(5):578-581.

26. Couto SS, Griffey SM, Duarte PC, Madewell BR: Feline vaccine-associated fibrosarcoma: morphologic distinctions. Vet Pathol 2002, 39(1):33-41.

27. Doddy FD, Glickman LT, Glickman NW, Janovitz EB: Feline fibrosarcomas at vaccination sites and non-vaccination sites. J Comp Pathol 1996, 114(2):165-174.

28. Hendrick MJ, Brooks JJ: Postvaccinal sarcomas in the cat: histology and immunohistochemistry. Vet Pathol 1994, 31(1):126-129. 
29. Romanelli G, Marconato L, Olivero D, Massari F, Zini E: Analysis of prognostic factors associated with injection-site sarcomas in cats: 57 cases (2001-2007). J Am Vet Med Assoc 2008, 232(8):1193-1199.

30. Wilcock B, Wilcock A, Bottoms K: Feline postvaccinal sarcoma: 20 years later. Can Vet J 2012, 53(4):430-434.

\title{
OPIS FIBROSARKOMA KOD MAČKE NA MESTU INJEKCIJE UZ POSTOJANJE METASTAZA NA CEREBELUM
}

\author{
CORA Roxana, GAL Adrian Florin, TAULESCU Marian, TĂBĂRAN Flaviu, \\ VIDRIGHINESCU Raluca, CĂTOI Cornel
}

Hendrick i Goldscmidt su 1991. godine prvi opisali sarkome na injekcionim situsima kod mačaka. Pojava sarkoma na mestu vakcinacije, uslovila je da se ustali poseban termin - vakcinalni sarkom. U studiji se opisuje neobičan slučaj fibrosarkoma na mestu inokulacije uz postojanje metastazau malom mozgu. Radilo se o domaćoj kratkodlakoj mački staroj 7 godina koja je primljena na obdukciju na Katedru za patologiju, Fakulteta veterinarske medicine u Cluj-Napoca (Rumunija). Uočen je supkutani tumor (relaps) u interskapularnoj regiji kao i veći broj metastaza u plućima, bubrezima, potkožnom tkivu (regije skapule i ekstremiteta) kao i u cerebelumu. Obavljena su citološka, histološka i imunohistohemijska ispitivanja (na vimentin, dezmin, citokeratin, $\alpha$-aktin glatkih mišića, S100 i CD45) svih uzoraka tkiva tumora. Citološkim ispitivanjem, uočene su izrazito pleomorfne, vretenaste ćelije zajedno sa neoplastičnim multijedarnim gigantocitima. Histološki, sve neoplastične mase su se sastojale iz većeg broja vretenaste ćelija koje su bile organizovane u ispreplitane grupice. U tkivima tumora, bila je naglašena nekroza zajedno sa infiltracijom neutofila. Zajedno sa neoplastičnim ćelijama uočene su fibrilarne strukture (zeleno obojene primenom Masson-ove trihrom metode), što ukazuje na kolagenu strukturu. Kod svih tumorskih tkiva koja su ispitivana imunohistohemijski, bila je uočena intenzivna reakcija samo na vimentin i to kod većeg broja neoplastičnih ćelija. $\mathrm{Na}$ osnovu anamneze, patomorfološkog, citološkog, histološkog i imunohistohemijskog nalaza, postavljena je konačna dijagnoza tj. rekurentan fibrosarkom injekcionog situsa mačaka uz postojanje brojnih metastaza (uključujući i cerebelum). Opisan je neobičan slučaj fibrosarkoma injekcionog situsa mačaka. Radi se o prvom opisanom slučaju sarkoma injekcionog situsa mačaka sa metastazama u cerebelumu. 